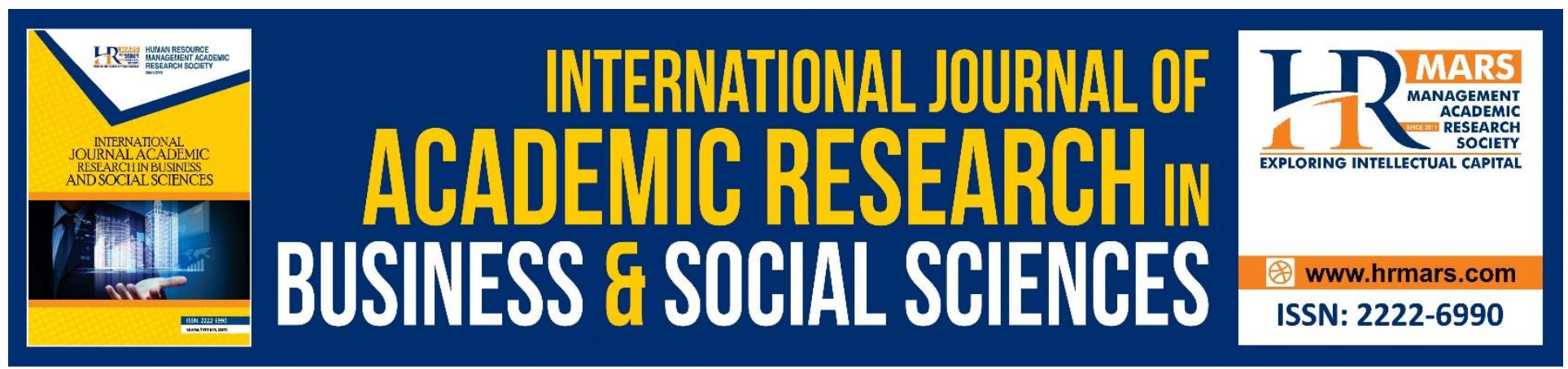

\title{
The Intention to Use on e-Learning Portal: A Case Study of i-Learn Portal at Universiti Teknologi MARA Cawangan Kelantan
}

Ibhrahim Zakaria, Norazlan Anual, Mazuin Mat Halif, Marhainis Jamaluddin, Wan Saiful Azzam Wan Ismail and Norfadzilah Ariffin

To Link this Article: http://dx.doi.org/10.6007/JJARBSS/v8-i11/4948

DOI: $10.6007 /$ IJARBSS/v8-i11/4948

Received: 26 Oct 2018, Revised: 17 Nov 2018, Accepted: 30 Nov 2018

Published Online: 07 Dec 2018

In-Text Citation: (Zakaria et al., 2018)

To Cite this Article: Zakaria, I., Anual, N., Halif, M. M., Jamaluddin, M., Ismail, W. S. A. W., \& Ariffin, N. (2018). The Intention to Use on e-Learning Portal: A Case Study of i-Learn Portal at Universiti Teknologi MARA Cawangan Kelantan. International Journal of Academic Research in Business and Social Sciences, 8(11), 711-721.

Copyright: (C) 2018 The Author(s)

Published by Human Resource Management Academic Research Society (www.hrmars.com)

This article is published under the Creative Commons Attribution (CC BY 4.0) license. Anyone may reproduce, distribute, translate and create derivative works of this article (for both commercial and non-commercial purposes), subject to full attribution to the original publication and authors. The full terms of this license may be seen

at: http://creativecommons.org/licences/by/4.0/legalcode

Vol. 8, No. 11, 2018, Pg. 711 - 721

http://hrmars.com/index.php/pages/detail/IJARBSS

JOURNAL HOMEPAGE

Full Terms \& Conditions of access and use can be found at http://hrmars.com/index.php/pages/detail/publication-ethics 


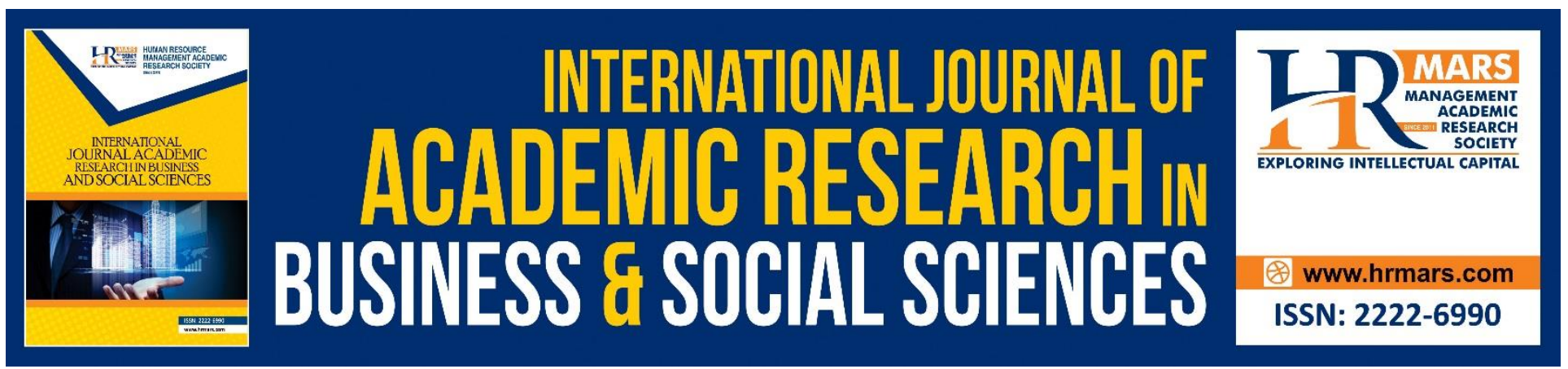

\section{The Intention to Use on e-Learning Portal: A Case Study of i-Learn Portal at Universiti Teknologi MARA Cawangan Kelantan}

Ibhrahim Zakaria ${ }^{1}$, Norazlan Anual' ${ }^{1}$, Mazuin Mat Halif ${ }^{1}$, Marhainis Jamaluddin², Wan Saiful Azzam Wan Ismail² and Norfadzilah Ariffin ${ }^{2}$

${ }^{1}$ Faculty of Business and Management,Universiti Teknologi MARA, Malaysia

${ }^{2}$ Faculty of Computer and Mathematical Sciences, Universiti Teknologi MARA, Malaysia

\section{Abstract}

The development of information technology has contributed to the growth in e-learning as an additional educational method. E-learning provides the opportunities for the academician to share their knowledge, resources and expertise in a diverse way. E-learning supports learners with some special capabilities such as interactivity, strong search, immediacy, physical mobility and situating of educational activities, self-organized and self-directed learning, corporate training, personalized learning and effective technique of delivering lesson and gaining knowledge. The model for the framework was adopted from Hassanzaneh, Kannani and Elahi (2012). 100 respondents were the individual students who are currently bachelor's degree students whom used the i-Learn Portal at Universiti Teknologi MARA (UiTM) Cawangan Kelantan in their learning activities. The findings confirmed that Service Quality; Technical System Quality; and Content and Information Quality significantly influence the intention to use i-Learn Portal at UiTM Cawangan Kelantan. However, the findings also confirm that Educational Quality does not significantly influence the intention to use iLearn Portal at UiTM Cawangan Kelantan. UiTM Cawangan Kelantan needs to upgrade the educational quality used in order to provide a conducive learning environment for learners for different types of user's learning style and the university should upgrade its Wi-Fi connection bandwith to enable students to open the i-Learn portal anytime, anywhere in the campus.

Keywords: Users, Usage, Intentions, E-Learning Portal, Educational Quality, Service Quality, Technical System Quality, Information Quality

\section{INTRODUCTION}

Coping with the latest development of Internet technologies, universities are investing considerable resources in implementing e-learning system to support teaching and learning activities. E-learning system implemented features to disseminate knowledge sharing and online collaboration between academician and students all over the Internet. E-learning system facilitates educator- 
students communication; tracking student's progress; and secure sharing of course content online (Islam, 2013). The implementation of e-learning system by the universities has promised better quality and learning-centered education because Internet has made teaching and learning available anytime and anywhere with no boundaries.

However, despite all the benefits of using e-learning system to support teaching and learning, the effectiveness of e-learning depends on the level of individual and social support available when it is adopted (Cho and Lai, 2019; (Lia, Chen, Sun, Wible and Kuo, 2010). The ability to collaborate with remotely-located peers may address learner's social needs and make them more satisfied with online learning and motivated to use it (Salas, Kosarzycki, Burke, Fiore and Stone, 2002). Learners may also be more satisfied and keen to continue their learning if they have able to control and customize their learning, as their learning experiences will then be a better fit with their preferences (Derouin, Fritzsche and Salas, 2005). Therefore, it can be concluded that e-learning usage depends on the role of individual attitudes towards technology. If the e-learning system fit the user's learning style or preferences, they will use the system and experiences more enjoyable on their e-learning activities as compared to those who find it difficult to adopt the e-learning systems (Ahmad, 2010). Four dimensions have been identified to measure the user's intention to use the e-learning system adopted. Those dimensions are as follows: educational quality, service quality, technical system quality and content and information quality. The model which has been adopted by Hassanzadeh, Kanaani and Elahi (2012) explained the influence educational, service, technical system and information quality features on the users' usage intentions, and using survey data from the students whom uses the i-Learn Portal of UiTM Cawangan Kelantan.

\section{LITERATURE REVIEWS}

Intention to Use: Intention to use is defined as the likelihood that an individual will use an information system (Schierz, Schilke and Wirtz, 2010). Intention to use plays a critical role in the actual use of a new technology and can also be considered as an attitude towards the information system adopted (DeLone and McLean, 2003). Thus, it is important to understand the role of individual attitudes toward technology, since e-learning usage depends on it. As new generations of e-learning technology, such as podcasts, wikis and blogs, enter workplaces-being able to quickly adopt and use them for one's training becomes a valuable skill because it means greater control over one's learning environment-individuals can try different tools, and pick and choose which ones fit their needs and preferences best. Individuals who, on the other hand, are less able to adopt new tools may be stuck with e-learning from the previous generations which may be less customizable, less portable, and difficult to query, making their e-learning experience less enjoyable. Individuals who are better able to adopt new tools may start using them if the new tools fit their learning styles or preferences better, while those who find it difficult to adopt new systems may be trapped into using systems that they do not like (Ahmad, 2010).

E-Learning: E-learning system is a web-based communication platform that allows learners, without limitations on place and time, to access diverse learning tools such as discussion boards, assessments, content repositories and document sharing systems (Martins and Kellermanns, 2004); (Ngai, Poon and Chan, 2007). E-learning makes learning more accessible because not only can individual study 
INTERNATIONAL JOURNAL OF ACADEMIC RESEARCH IN BUSINESS AND SOCIAL SCIENCES Vol. 8, No. 11, Nov, 2018, E-ISSN: 2222-6990 @ 2018 HRMARS

when it is convenient for them, but they also have access to coaching and support potentially roundthe-clock (Soheila and Singh, 2015). Nowadays, e-learning quickly becoming a vital part of the learning and teaching process (Pituch and Lee, 2006) because it makes communication among learners and between learner and instructor/teachers more efficient (Martins and Kellermanns, 2004).

Educational Quality: Educational quality is the extent to which an information system managed to provide a conducive learning environment for learners in collaborative learning (Hassanzadeh, Kanaani and Elahi, 2012); (Kim, Trimi, Park and Rhee, 2012). It also helps to facilitate users learning and training by rendering the information system's characteristics and features (Hassanzadeh, Kanaani and Elahi, 2012). Educational quality helps influences users' satisfaction in using the information system. Previous studies conducted by Hassanzadeh, Kanaani and Elahi, (2012); Kim, Trimi, Park and Rhee, (2012) confirmed that educational quality have a significant positive effect on user's satisfaction.

Service Quality: Service quality is the extent to which the support that the user receive while using the information system (Wang and Wang, 2009). Service quality helps influences the user's satisfaction in using the information system. Previous studies confirmed that the quality of support the user receive while using the information system have a significant positive effect on user's satisfaction in e-learning context (Poulova and Simonova, 2014); (Roca, Chiu and Martinez, 2006); (Tajuddin, Baharudin and Hoon, 2013); (Wang and Chiu, 2011) and on intention to use e-learning system (Cheng, 2012); (Hassanzadeh, Kanaani and Elahi, 2012); (Ramayah, Ahmad and Lo, 2010); (Wang and Chiu, 2011).

Technical Service Quality: Technical system quality refers to the technical success and the accuracy and efficiency of the communication system that produce information (DeLone and McLean, 2003). Technical system quality is a part of desirable characteristics and measures of an information system and relates to the presence and absence of a bug in a system (Islam, 2013). Technical system quality have a significant positive effect on satisfaction in e-learning context (Hassanzadeh, Kanaani and Elahi, 2012); (Islam, 2013); (Kim, Trimi, Park and Rhee, 2012); (Tajuddin, Baharudin and Hoon, 2013); (Wang and Chiu, 2011); (Wu, Tennyson and Hsia, 2010), and on intention to use e-learning system (Cheng, 2012); (Islam, 2013); (Li and Kishore, 2006); (Ramayah, Ahmad and Lo, 2010)

Content and Information Quality: Content and information quality refers to the quality of the information that the system generates and its usefulness for the user (Hassanzadeh, Kanaani and Elahi, 2012). It is also one of the desirable characteristic that the information system's success factor and often seen as key antecedent for user satisfaction (Hassanzadeh, Kanaani and Elahi, 2012); (Kim, Trimi, Park and Rhee, 2012); (Roca, Chiu and Martinez, 2006); (Wang and Chiu, 2011) and for intention to use e-learning system (Cheng, 2012); (Ramayah, Ahmad and Lo, 2010); (Wang and Chiu, 2011).

\section{CONCEPTUAL FRAMEWORK}

Fig. 1 shows the conceptual framework of this study. The independent variables for this study are the dimensions of e-learning success model success adopted from Hassanzadeh, Kanaani and Elahi, 
(2012). Meanwhile, the dependent variable in this study reflects the outcome of this research study which is intention to use. There are four (4) dimensions served as independent variables e-learning success model which consist of educational quality; service quality; technical system quality; and content and information quality. Those dimensions were correlated to assist in investigating the relationship between educational, service, technical system and information quality features on Intention to Uses on i-Learn Portal at UiTM Cawangan Kelantan.
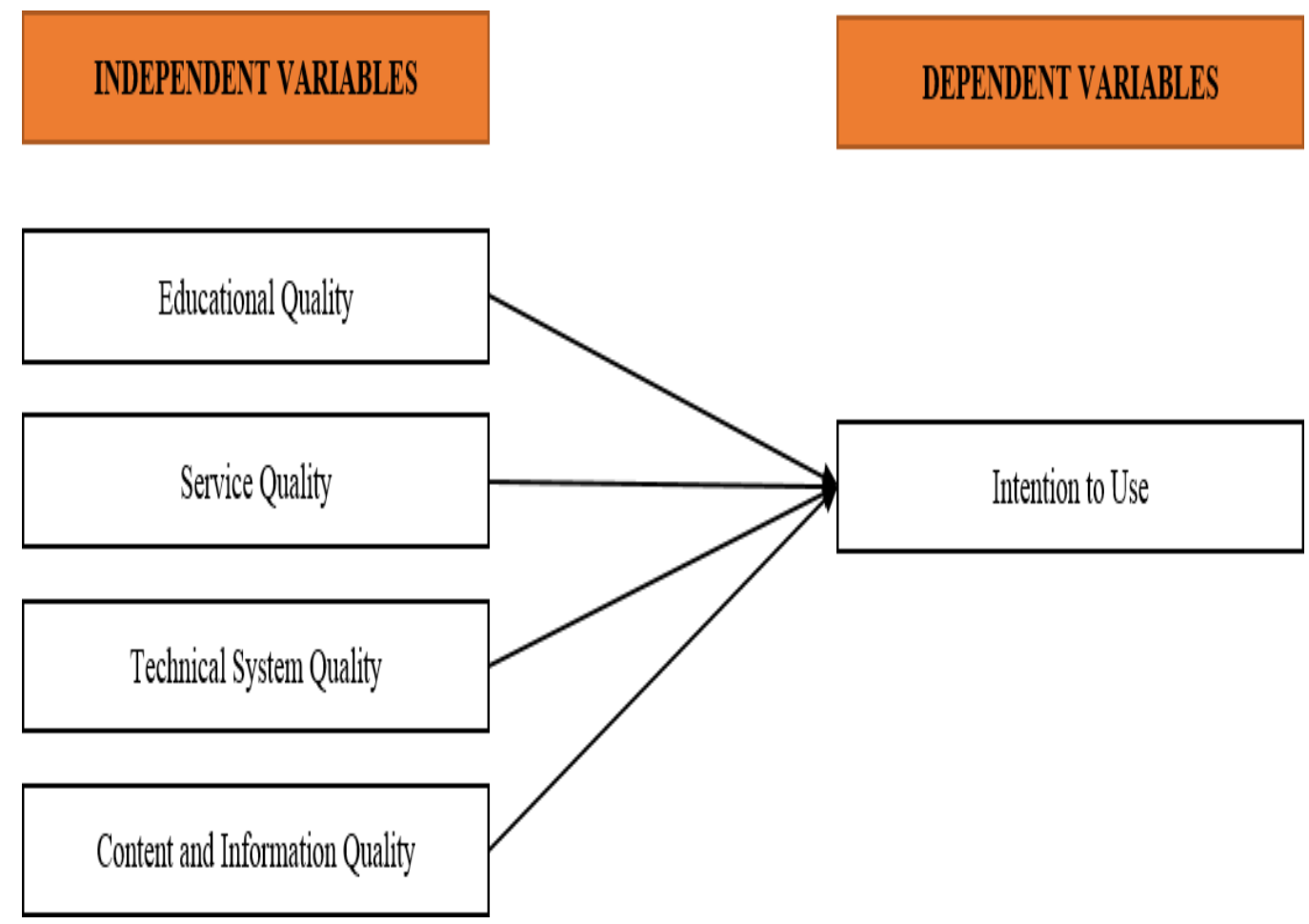

Fig. 1: Research Model.

\section{HYPOTHESIS}

Based on the review of the related literature, the following research hypotheses were developed: $\mathrm{H}_{1}$ Educational quality significantly influences intention to use.

$\mathrm{H}_{2}$ Service quality significantly influences intention to use.

$\mathrm{H}_{3}$ Technical system quality significantly influences intention to use.

$\mathrm{H}_{4}$ Content and Information quality significantly influences intention to use.

\section{METHODOLOGY}

The study meant to investigate the relationships between i-Learn Portal used at UiTM Cawangan Kelantan and the users' usage intention. Therefore, correlation and multiple regression analysis were used. 100 respondents were the individual students who are currently bachelor's degree students whom used the i-Learn Portal at UiTM Cawangan Kelantan in their learning activities. Samples for the study were derived using convenience sampling technique and were analyzed by using SPSS V23.

\section{RESULTS AND FINDINGS}

\section{Demographic Profile}


INTERNATIONAL JOURNAL OF ACADEMIC RESEARCH IN BUSINESS AND SOCIAL SCIENCES Vol. 8, No. 11, Nov, 2018, E-ISSN: 2222-6990 @ 2018 HRMARS

Based on the demographic result collected from the findings, it was found that the majority of the respondents at UiTM Cawangan Kelantan were female with $82 \%$ while male respondents were represented by only $18 \%$. The majority of the respondents are currently taking bachelor's degree from at UiTM Cawangan Kelantan where $58 \%$ of the respondents are from the Faculty of Business and Management while the other $42 \%$ of respondents are from the Faculty of Information Management.

Table I: Cronbach's Alpha Scores ( $n=100)$

\begin{tabular}{|l|l|l|l|}
\hline Section & Scale & Cronbach's Alpha & N of Items \\
\hline B & Educational Quality & .764 & 6 \\
\hline C & Service Quality & .595 & 6 \\
\hline D & $\begin{array}{l}\text { Technical System } \\
\text { Quality }\end{array}$ & .791 & 6 \\
\hline E & $\begin{array}{l}\text { Content and } \\
\text { Information Quality }\end{array}$ & .880 & 6 \\
\hline F & Intention to Use & .892 & 6 \\
\hline
\end{tabular}

Table I shows the reliability statistics for the each e-learning success model and Intention to Use. For each of the success model, it was found that the reliability statistics score were closer to 1. Educational Quality indicates score of .764, Service Quality (.595), Technical System Quality (.791), Content and Information Quality (.880) and Intention to Use (.892). According to [24] the closer the result to 1 , the more reliable would be the test. Reliability values less than .60 are considered as poor, those around .70 are acceptable and those over .80 are good. Therefore, it can be concluded that the questionnaire accurately measures what it is supposed to measure.

\section{Correlation Analysis}

Table II: Correlational Table $(n=100)$

\begin{tabular}{|l|l|l|l|l|l|l|l|}
\hline Variables & Mean & SD & Mean EQ & Mean SQ & Mean TSQ & Mean IQ & Mean UUI \\
\hline Mean EQ & 3.515 & .538 & & & & & \\
\hline Mean SQ & 3.663 & .394 & $.438^{* *}$ & & & & \\
\hline Mean TSQ & 3.605 & .490 & $.422^{* *}$ & $.584^{* *}$ & & & \\
\hline Mean IQ & 3.658 & .540 & $.334^{* *}$ & $419^{* *}$ & $.596^{* *}$ & & \\
\hline Mean UUI & 3.715 & .565 & $.280^{* *}$ & $.565^{* *}$ & $.557^{* *}$ & $.504^{* *}$ & \\
\hline
\end{tabular}

**. Correlation is significant at the 0.01 level (2-tailed).

Table II indicates that there is a weak and positive relationship between Educational Quality and Intention to Use. $(p<.05, r=.280)$. Apart from that, there is a moderate and positive relationship between Service Quality and Intention to Use. $(p<.05, r=.565)$. In addition, there is a moderate and positive relationship between Technical System Quality and Intention to Use. ( $p<.05, r=.557)$ and there is a moderate and positive relationship between Information Quality and Intention to Use. $(p<.05, r=.504)$. The findings are similar to the study conducted by [25] in which the researcher stated that educational quality, service quality, technical system quality and information quality positively affect the Intention to Use towards e-learning. 
INTERNATIONAL JOURNAL OF ACADEMIC RESEARCH IN BUSINESS AND SOCIAL SCIENCES

Vol. 8, No. 11, Nov, 2018, E-ISSN: 2222-6990 @ 2018 HRMARS

\section{Hypothesis Testing}

Table III: The Influence of e-Learning Success Model on Intention to Use $(n=100)$

\begin{tabular}{|l|l|l|l|}
\hline Model & Standardized Coefficient (Beta) & $\mathbf{t}$ & Sig. \\
\hline Mean EQ & -.052 & -.586 & .559 \\
\hline Mean SQ & .353 & 3.573 & .001 \\
\hline Mean TSQ & .233 & 2.126 & .036 \\
\hline Mean IQ & .235 & 2.418 & .018 \\
\hline R Square & .433 & & \\
\hline Adjusted R Square & .410 & & \\
\hline R Square Change & .433 & & \\
\hline F Value & 18.171 & & \\
\hline Significant F Value & .000 & & \\
\hline Durbin-Watson & 1.524 & & \\
\hline
\end{tabular}

\section{$H_{1}$ : Educational Quality significantly influences intention to use.}

Table III shows that, Educational Quality does not significantly influences Intention to use i-Learn Portal at UiTM Cawangan Kelantan, $(\beta=-.052, p>.01)$. Therefore, hypothesis $\mathrm{H}_{1}$ which hypothesizes that Educational Quality significantly influence intention to use is rejected.

\section{$\mathrm{H}_{2}$ Service Quality significantly influences intention to use.}

Table III shows that, Service Quality significantly influences Intention to use i-Learn Portal at UiTM Cawangan Kelantan, $(\beta=.353, \mathrm{p}<.01)$. Therefore, hypothesis $\mathrm{H}_{2}$ which hypothesizes that Service Quality significantly influence intention to use is accepted.

\section{$\mathrm{H}_{3}$ Technical System Quality significantly influences intention to use.}

Table III shows that, Technical System Quality significantly influences Intention to use i-Learn Portal at UiTM Cawangan Kelantan, $(\beta=.233, \mathrm{p}<.01)$. Therefore, hypothesis $\mathrm{H}_{3}$ which hypothesizes that Technical System Quality significantly influence intention to use is accepted.

\section{$\mathrm{H}_{4}$ Content and Information Quality significantly influence intention to use.}

Table III shows that, Content and Information Quality significantly influences Intention to use iLearn Portal at UiTM Cawangan Kelantan, $(\beta=.235, \mathrm{p}<.01)$. Therefore, hypothesis $\mathrm{H}_{4}$ which hypothesizes that Content and Information Quality significantly influence intention to use is accepted.

\section{CONCLUSION}

As a conclusion, the findings confirm that Service Quality; Technical System Quality; and Content and Information Quality significantly influence the intention to use i-Learn Portal at UiTM Cawangan Kelantan. However, the findings also confirm that Educational Quality does not significantly influence the intention to use i-Learn Portal at UiTM Cawangan Kelantan.

The attitude of the students could provide a guideline in helping the optimal way towards satisfied long learning programs through e-learning portal. Therefore, this research shed some lights on the preferences and attitudes of the students in using e-learning which can be regarded as longterm benefits. Hence, designing appropriate e-learning tools, conducting surveys of attitudes and 
opinion of the students on the education via e-learning is useful especially to the developers and teachers as a whole.

It is necessary for developers and teachers to accept the fact that virtual learnings has become important and a prudent mixture between traditional learning and modern techniques of teaching can increase lifelong learning based on the use of modern information and communications technologies. Teachers just have to find out ways to attract students with these combinations.

E-learning is not just a new attempt. This kind of education like traditional systems of educations has its own barriers and necessities which should be considered for achieving learning outcomes specifically and university's goals in general. Education is not restricted in special place like university. All learners are not restricted to time and place and new education should help the students to learn how to learn, and what to learn

\section{SUGGESTIONS FOR FUTURE RESEARCH}

Since this study is limited to only UiTM Cawangan Kelantan, it is suggested that the same study could be prolonged to other campuses or other universities that use e-learning portal in teaching and learning.

It is suggested that future research should consider conducting a longitudinal research study in students' opinions on e-learning. It is important that when implementing e-learning portal, students' suggestions need to be considered as they are the most important elements of this process. Students will surely share their opinions and needs. However, it is also important to note that not all subjects are suitable in e-learning. Some complex and technical subjects do need a classic classroom teaching and learning. Therefore, researchers should consider conducting a survey in identifying the suitable subjects or courses or even topic to be included in e-learning initiative.

There are numerous challenges faced by lecturers in using ICT in universities. ICT brings with it various challenges that lecturers need to face. Another challenge is that lecturers need to develop their own capacity so as to efficiently make use of the different ICTs in different situations. Further research should include studying lecturers' perceptions and apprehensiveness in using e-learning portal themselves. Language can also be additional elements in this issue as English has become the prominent language associated with modern technology. This could happen when English is not the main medium of communication in delivering lectures.

Other issues for future research could include possible differences in perception between male and female learners that could possibly give different result. This is especially possible when male students are known to be visual learners and female students are more to verbal learners. Results of such survey could certainly vary and influence the intention to use e-learning portal.

\section{MANAGERIAL IMPLICATIONS}

In designing and developing e-learning products, UITM should actually involve a careful mixture of personnel resources, standards for interactivity and media, and design parameters based on user capabilities. This includes a proper training for lecturers and a complete manual on the step by step process in conducting and applying e-learning. The effort by UiTM in developing and building its own product is certainly beneficial but at the same time, this development should be aligned with the 
curriculum development, technical pedagogical knowledge, the content knowledge and the place for delivering the course.

The content of the product is also an important issue to be dealt with. It is advisable that a combination use of text, static visual animation, dynamic visual animation, a multimedium, animation, simulation and so on are also vital elements in achieving educational goals in the cognitive, affective, and/or psychomotor field. It is important to note that students' favorite elements of elearning materials are the dynamic ones. This is in the form of interactive educational simulations, followed by static elements in the form of texts and images.

It is pertinent that the content should match the goals to be achieved. Therefore, UiTM as the developer should also consider a mixture of printed educational materials, designed for distance learning, apart from having electronic forms (e-learning, e-blending and so on). This is important as UiTM need to understand the basic learning styles of students that include the verbal learners and visual learners.

UiTM Cawangan Kelantan needs to upgrade the educational quality used in order to provide a conducive learning environment for learners for different types of user's learning style (Hassanzadeh, Kanaani and Elahi, 2012); (Kim et., al, 2012). UiTM Cawangan Kelantan should upgrade its Wi-Fi connection bandwidth to enable students to open the i-Learn portal anytime, anywhere in the campus. Moreover, the e-learning portal used should also feature technical system that are user friendly, flexible, secure and aesthetically satisfying to the users so that students can enjoy using the technology provided for them (Mohammadi, 2015), (Ahmad, 2010). The issue doesn't last with preparing computer provision for learners. Maintaining the facilities is another important factor that can jeopardize the process of learning itself. UiTM should always consider maintaining as an important subject when preparing the budget for e-learning purposes. The costs of maintaining include considering other elements such as updating anti-virus, information security issues and etc.

In all, UiTM should conduct a survey on the learner's facilities at their home. This is an important factor that helps them in the communication process in e-learning. Learners with computer at home were much more confident, an IT literate and likely to use ICT more extensively at the university. An access to internet is another issue. It is vital that the internet connection is stable especially in the university. Poor internet connection consume more time to complete the work or assignments given and thus, demotivate the student's intention to use the e-learning portal.

\section{ACKNOWLEDGEMENT}

First and foremost, the researcher would like to give thanks to Allah SWT for seeing me through what initially seemed like an impossible journey. Next my appreciation goes to UiTM as my main sponsor for this research (ARAS Grant 600-IRMI/DANA 5/3/ARAS (0050/2016). The researcher also would like to express my appreciation to my fellow colleagues, Norazlan Anual, Mazuin Mat Halif, Marhainis Jamaluddin, Wan Saiful Azzam Wan Ismail and Norfadzilah Ariffin. Last but not least, to my dearest friends, thank you for the comments and support especially during the completion of this study. It is a wonderful moments throughout the completion of this study. 
INTERNATIONAL JOURNAL OF ACADEMIC RESEARCH IN BUSINESS AND SOCIAL SCIENCES

Vol. 8, No. 11, Nov, 2018, E-ISSN: 2222-6990 @ 2018 HRMARS

\section{Corresponding Author}

Ibhrahim Zakaria, Faculty of Business and Management, Universiti Teknologi MARA Cawangan

Kelantan, Malaysia, Email: ibhrah2939@kelantan.uitm.edu.my.

\section{REFERENCES}

Ahmed, H. M. S. (2010). Hybrid e-learning acceptance model: learner perceptions. Decision Sciences Journal of Innovative Education, 8(2), 313-346.

Cheng, M. Y. (2012). Effects of quality antecedents on e-learning acceptance. Internet Research, 22(3), 361-390.

Cho, V., Cheng, T., \& Lai, W. (2009). The role of perceived user-interface design in continued usage intention of self-paced e-learning tools. Computers \& Education, 53(2), 216-227.

DeLone, W. H., \& McLean, E. R. (2003). The DeLone and McLean model of information systems success: A ten year update. Journal of Management Information Systems, 19(4), 9-30.

Derouin, R. E., Fritzsche, B. A., \& Salas, E. (2005). E-learning in organizations. Journal of Management, 31(6), 920-940.

Hassanzadeh, A., , Kanaani, F., \& Elahi, S. (2012). A model for measuring e-learning systems success in universities. Expert Systems with Applications, 39, 10959-10966.

Islam, A. K. M. (2013). Investigating e-learning system usage outcomes in the university context. Computers \& Human, 69, 387-399.

Li, J. P., \& Kishore, R. (2006). How robust is the UTAUT instrument? A multigroup invariance analysis in the context of acceptance and use of online community web blog systems, presented at ACM Conference on Computer Personnel Research, 2006. Claremont, California, USA.

Liu, I. F., Chen, M. C., Sun, Y. S., Wible, D., \& Kuo, C. H. (2010). Extending the TAM model to explore the factors that affect intention to use an online learning community. Computers \& Education, 54(2), 600-610.

Kim, K., Trimi, S., Park, H., \& Rhee, S. (2012). The impact of CMS quality on the outcomes of e-learning systems in higher education: An empirical study. Decision Sciences Journal of Innovative Education, 10(4), 575-587.

Martins, L. L., \& Kellermanns, F. W. (2004). A model of business school students' acceptance of a webbased course management system. Academy of Management Learning \& Education, 3(1), 7-26.

Mohammadi, H. (2015). Investigating users' perspectives on e-learning an integration of TAM and IS success model. Computers in Human Behavior, 45, 359-374. DOI: 10.1016/j.chb.2014.07.044

Ngai, E., Poon, J., \& Chan, Y. (2007). Empirical examination of the adoption of WebCT using TAM. Computers \& Education, 48(2), 250-267.

Pituch, K. A., \& Lee, Y. (2006). The influence of system characteristics on e-learning use. Computers \& Education, 47(2), 222-244.

Poulova, P., \& Simonova, I. (2014). E-learning reflected in research studies in Czech Republic: Comparative analyses. Procedia-Social and Behavioral Sciences, 116, 1298-1304.

Salas, E., Kosarzycki, M. P., Burke, C. S., Fiore, S. M., \& Stone, D. L. (2002). Emerging themes in distance learning research and practice: some food for thought. International Journal of Management Reviews, 4(2), 135-153. 
Schierz, P., Schilke, O., \& Wirtz, B. (2010). Understanding customer acceptance of mobile payment services: An empirical analysis. Journal of Electronic Commerce Research and Application, 9, 209216.

Sekaran, U., \& Bougie, R. (2010). Research Methods for Business: A Skill Building Approach (5th Edition). New York: John Wiley and Sons Limited.

Soheila, M., \& Singh, H. (2015). Understanding the effect of e-learning on individual performance: The role of digital literacy. Computers \& Education, 82, 11-25.

Ramayah, T., Ahmad, N. H., \& Lo, M. C. (2010). The role of quality factors in intention to continue using an e-learning system in Malaysia. Procedia-Social and Behavioral Science, 2, 5422-5426.

Roca, J., Chiu, C. M., \& Martinez, F. J. (2006). Understanding e-learning continuance intention: An extension of the technology acceptance model. International Journal of Human-Computer Studies, 64, 683-696.

Tajuddin, R., Baharudin, M., \& Hoon, T. S. (2013). System quality and its influence on students' learning satisfaction in UiTM Shah Alam. Procedia Social and Behavioral Science, 90, 677-685.

Wang, W. T., \& Wang, C. C. (2009). An empirical study of instructor adoption of web-based learning systems. Computers \& Education, 53, 761-774.

Wang, H. C., \& Chiu, Y. F. (2011). Assessing e-learning 2.0 system success. Computers \& Education, 57, 1790-1800.

Wu, J. H., Tennyson, R. D., and Hsia, T. L. (2010). A study of student satisfaction in a blended e-learning system environment. Computers \& Education, 55, 155-164. 